\title{
FYZIOTERAPIE V SOUČASNÉ MODERNÍ MEDICÍNĚ
}

Marek Zeman

11: 467-470, 2009

ISSN $1212-4117$

Bertiny lázně Třeboň, s. r. o.

Jihočeská univerzita v Českých Budějovicích, Zdravotně sociální fakulta, katedra klinických oborů

\section{ÚVOD}

Fyzioterapie jako nesmírně dynamicky se rozvíjející obor si zasluhuje v medicíně, ale i ve zdravotně sociálních vědách naši oprávněnou pozornost. Právě obrovský vývoj tohoto oboru nám dnes ale současně přináší některé zajímavé otázky a problémy k řešení.

Jedná se např́iklad o určitou míru komercionalizace některých př́stupů $\mathrm{v}$ kinezioterapii, která souvisí s rozšířením nejrůznějších wellness a fitness středisek, obrovskou mediální prezentací správného životního stylu a úspěšného života zahrnujícího péči nejen o psychiku, ale i o pohybový aparát apod.

Tyto dozajista př́kladné tendence mohou u některých klientů vzbudit falešnou představu o tom, že zdraví, resp. bezbolestný stav a vyřešení aktuálních problémů pohybového aparátu lze koupit a veškerá námaha, která je vynakládána na obnovení zdraví, je pouze záležitostí ošetrujuícího personálu, a ne vlastního príčinění.

Proto je velmi důležitá vhodná forma edukace, tedy vysvětlení vhodných postupů, kterými může sám klient svůj zdravotní stav změnit a veškeré terapeutické snahy zdravotníka tak efektivizovat.

\section{Pojem rehabilitace, fyzioterapie}

Rehabilitace ( $z$ lat. re $=$ předpona ve významu návratu či opakování děje; habilis = způsobilý, vhodný) - může být definována několikerým způsobem.

Dle WHO (Světové zdravotnické organizace) „zahrnuje všechny prostředky, směřující ke zmírnění tíže omezujících a znevýhodnujících stavů a umožňuje zdravotně postiženým a handicapovaným osobám dosáhnout sociální integrace“. Dle profesora Jandy „představuje soubor opatření, která vedou $\mathrm{k}$ co nejoptimálnější a nejrychlejší resocializaci člověka postiženého na zdraví následkem nemoci, úrazu nebo vrozené vady“ (Dylevský, 2001).
Fyzioterapie ( $\mathrm{z}$ řec. physis = příroda; therapeia $=$ léčenî) je medicínský obor, který využívá přírodních podnětů $\mathrm{k}$ zachování či obnově zdraví.

Základním cílem fyzioterapie je léčba funkčních poruch pohybového aparátu, mezi něž řadíme např. blokády kloubů, svalové spasmy a další, s využitím anatomických a fyziologických poznatků pohybového aparátu (Dvořák, 2003).

Z uvedených definic je zřejmé, že pojem rehabilitace je v určitém slova smyslu zastřešující pro všechny obory zdravotnické, ale i ekonomické, sociální, politické, pedagogické, psychologické, technické atd. (Javůrek, 1999). Jinými slovy je fyzioterapie pouze součástí celkové rehabilitace, hovoříme taktéž o komplexní (komprehenzivnî) rehabilitaci.

\section{Zvláštnosti postavení fyzioterapie $\mathbf{v}$ medicíně}

Fyzioterapie je poměrně specifickou medicínskou oblastí. Na rozdíl od jiných oborů pracuje s pohybovým aparátem jako celkem a snaží se nejen „vyléčit", ale i zkvalitnit a zlepšit jeho funkce (Gúth, 2004).

Např. v kožním lékařství můžeme obecně říci, že je dána určitá „norma“, např. nepřítomnost bradavice, a nějaký chorobný stav, např. př́tomnost bradavice. Cílem je pak odstranění chorobného stavu vhodnou terapeutickou intervencí. $\mathrm{Na}$ tomto príkladu vidíme také klasický postup současné medicíny. Všichni lidé zpravidla nemají bradavici, jinými slovy: „normální je nemít bradavici“, proto je třeba ji nemocnému odstranit.

Fyzioterapie ovšem pracuje s pohybovým aparátem, u kterého je těžké stanovit normu (už proto, že populace neustále degeneruje), a také je tento pohybový aparát pořád aktivní a způsob jeho zatížení se neustále mění (Rychlíková, 2002). Najít nějaký kompromis mezi přirozenou 
degenerací organismu vlivem stáří a mezi degenerací, kterou podporujeme svým chováním (v zaměstnání, trávením volného času apod.), je nesmírně těžké. Krom toho stav pohybového aparátu ovlivňuje ostatní tělní systémy.

Fyzioterapie nabízí klientům dostatek možností a informací, jak o sebe pečovat. $V$ př́padě, že je klient využije a nebude stižen žádnými dalšími závažnými chorobami, je schopen se dožít s většími nebo menšími obtížemi standardního věku a může fungovat v životě prakticky normálním způsobem.

\section{Význam fyzioterapie pro dnešní společnost}

Dnešní populace je co do kvality pohybového aparátu, tj. svalové síly, balance a čistoty pohybových stereotypů dle slov „guru“ české rehabilitace prof. Lewita doslova „prohnilá“.

Civilizace s sebou přinesla nepochybně mnoho dobrého, ale pro tělesnou schránku ještě více špatného. Situace je opravdu vážná až alarmující. Absence smysluplné tělesné výchovy na všech typech škol, převážně základních a středních, nedostatek volnočasové pohybové aktivity u dětí, absence základních edukačních principů ve školách, osvěta $\mathrm{v}$ rodinách, systém primární prevence a záchytu a tak dále a tak dále.

Dnešní člověk koná zpravidla nemanuální práci, tráví většinu času $\mathrm{v}$ kancelářích se špatným osvětlením, špatným ergonomickým designem svého pracoviště (židle, stůl apod.), cestuje nejrůznějšími dopravními prostředky, nevyvijí soustavnou pohybovou aktivitu (Ištoňová, 2008). A právě poslední položka předchozí věty je velmi podstatná. Je jasné, že civilizaci, resp. její výdobytky a „raketový“ vývoj člověk neovlivní (ono to současně postrádá smysl), ale co může ovlivnit je své postavení $\mathrm{v}$ této civilizaci. Měl by si uvědomit, $\mathrm{k}$ čemu mu vlastně jeho tělesná schránka má sloužit, a pokud má sloužit dobře, jak zapracovat na tom, aby sloužila co nejdéle a nejlépe.

\section{Ekonomika zdravotnictví}

Systém zdravotnické péče je z ekonomického hlediska ve zvláštním postavení. Setkávají se zde totiž aspekty nejen ekonomické, ale i morální.

Je jisté, že koncepce poskytování zdravotní péče pojišt'ovnami vychází z reálných možností systému daného státu (Samuelson, 1995). Ten je limitován ekonomicky i počtem „potřebných“.
V souvislosti se zvyšujícím se počtem onemocnění pohybového aparátu se zvyšují finanční nároky na jejich léčbu (Tomeš, 2001).

Domnívám se, že do budoucna může být situace ještě problematičtější, zvláště u léčby degenerativních onemocnění. Ekonomika každého státu, at' už je na tom s hrubým domácím produktem lépe či hůře, nemůže být donekonečna schopna poskytovat veškerou nejmodernější zdravotní péči obecně všem potřebným v plném rozsahu (Zlámal, 2005). Nechci zde rozebírat komplikovanou otázku financování zdravotnictví, alokace zdrojů apod., chci jen upozornit, že, at' se nám to líbí nebo nelíbí, za zdraví každého z nás není odpovědna společnost, resp. stát, ale jen my sami a je jen na nás samých, jak se budeme o ně starat a využívat všech možností jeho upevnění a posílení, které nám jsou nabízeny.

Morální aspekty jsou daleko komplikovanější kapitolou. Obecně řečeno, celá medicína je určitým způsobem pomáhající profesí, kde morálka vysoce převyšuje všechny ostatní aspekty (Danzer, 2001). Od zdravotníka se očekává kromě vzdělání ještě něco jiného, a sice jistý typ pohnutky, láska k bližnímu či obecné odhodlání provozovat více či méně charitativní činnost (Žák, 2005). V každé chvíli svého jednání a konání se pak zdravotník musí rozhodnout, jestli bude své služby „dávat“, či „prodávat“", což je pochopitelně velmi složité.

\section{Dnešní zaměření fyzioterapie}

Fyzioterapie se v praxi provádí jak v nemocničním, tak v ambulantním sektoru. Oba sektory mají různé formy zrrízení, může se jednat o rehabilitační oddělení nemocnic, rehabilitační ústavy či polikliniky, lázně a různá další specializovaná pracoviště (Lewit, 2003).

Metody, které fyzioterapie používá, jsou nejrůznějš́ího charakteru. Jak už bylo zmíněno $\mathrm{v}$ předchozím textu, lidé trpí problémy pohybového aparátu čím dál více a fyzioterapie se tak z akutní terapeutické roviny daleko více přesouvá do roviny preventivní (Mikuláková, 2007). Jinak řečeno, klasické „rozcvičování“ po terapeutických zákrocích či úrazech je dnes v globálním pohledu na fyzioterapii $\mathrm{v}$ malém procentu. Lidé se snaží o své zdraví a správné fungování svého pohybového aparátu daleko více dbát a posunují tak de facto zaměření celé fyzioterapie spíše preventivním směrem. 
Fyzioterapeut vs. pacient, resp. klient

V souvislosti s předchozím odstavcem je nutné zmínit určitý posun v nahlížení na objekty medicínské péče. Donedávna univerzální označení nemocného „pacient“ dnes získává spíše pejorativní nádech a prosazuje se spíše „klient“, i když z toho výrazu už je př́liš patrný vliv tržního hospodářství. Avšak v celé medicíně je právě fyzioterapie prímo učebnicovým prríkladem fungování tržního hospodářství.

Jak už bylo řečeno, na rozdíl od ostatních medicínských oborů, které řeši aktuální zdravotní stav nemocného, pacienta (zde je slovo pacient pořád ještě pořád namístě), fyzioterapie se zabývá obtížemi, které nejsou zpravidla pro člověka aktuálně až tak významné, resp. nejsou život nebo zdraví bezprostředně ohrožující (Hromádková, 1999). Člověk, který vyhledává pomoc fyzioterapeuta, může samožrejmě v případě akutních obtíží očekávat uhrazení nákladů na péči zdravotní pojišt'ovnou, z hlediska dlouhodobějších obtíží však nikoli, a tak se stává platícím ,klientem“.

Laická argumentace tohoto faktu může být např. $v$ tom, že populace je $z$ hlediska stavu svého pohybového aparátu natolik špatná, že by „bolení krční páteře“" nebo „píchání v křriži“ nemohlo být terapeuticky dostatečně efektivně a hlavně z hlediska ekonomiky zdravotních pojišt'oven řešeno, už jenom z hlediska toho, že tyto problémy sužují prakticky každého z nás.

\section{Poskytování „služeb“ ve fyzioterapii}

Pro zdravotnické služby je i dnes typické, že jsou poskytovány vysoce kvalifikovanými pracovníky. Klient není zpravidla schopen posuzovat přiměřenost zdravotnických výkonů a jejich pŕínosy. Výsledný efekt projevující se na zdravotním stavu totiž jen omezeně reflektuje kvalitu výkonu, nebot' je výslednicí celé řady faktorů (Zlámal, 2005). Klient se musí spolehnout na úsudek terapeuta o tom, který léčebný přístup je pro něj nejvhodnější. Deleguje tedy svou spotřebitelskou suverenitu na terapeuta.

Navzdory faktu, že v poslední době vzniká v mnoha zemích řada sdružení pacientů, jejichž cílem je získávat a šírit informace o způsobech léčby určitých onemocnění, a mezi populací roste pravděpodobně i úroveň obecných znalostí o správném životním stylu, typická informační nerovnováha ve zdravotnictví přetrvává (Javůrek, 1999). Medicína a zvláště fyzioterapie jako věda nestojí, složitost léčebných procedur a techniky roste.

\section{Př́stup klientů $\mathrm{k}$ fyzioterapii}

Pro člověka, který se účastní fyzioterapie, je mnohem vhodnějším termínem (i z ekonomického hlediska) „klient“" než „pacient“.

Pacient, tedy z latiny „trpící“ je obvykle situován do role submisivnější, bez větších výhrad odevzdané zdravotníkovi. Tato role se ovšem mění. S rozvojem medicíny, informovanosti pacientů a vhodné mediální prezentace se dostává pacient do role klienta, který může a chce ovlivňovat léčebný proces. Čím více se fyzioterapie dostává od zaměření „doléčovacího“ nebo „rozcvičovacího“ do prístupu preventivního, tím více se pochopitelně prosazuje termín „klient".

Klient se totiž velmi často podílí na terapii finančně, což pochopitelně znamená, že mu není lhostejný průběh celé léčby. Pokud je např́klad klient $\mathrm{v}$ rámci príspěvkového léčebného pobytu v lázních, príijde ho celková léčba na nemalý obnos a rozhodně bude chtít vědět, jestli je aplikovaná terapie efektivní.

Některé firmy dopřávají svým zaměstnancům týdenní rekondiční pobyty $\mathrm{v}$ nejrůznějších rehabilitačních zařízeních nebo v lázních. Posilují tak pochopitelně jejich loajalitu $\mathrm{k}$ zaměstnavateli, ovšem současně monitorují jejich zdravotní stav. Pokud se ukáže, že jejich pohybový aparát není tak úplně bez problémů (což není prakticky u nikoho z nás), mohou se pokusit např́klad úpravou ergonomie pracoviště o zlepšení jejich pracovních podmínek.

Sám zaměstnanec se bude podobně snažit více využít nabídek fyzioterapie, aby ve velkém konkurenčním prostředí obstál a nebyl svými zdravotními obtížemi vůči ostatním spolupracovníkům handicapován.

\section{Dlouhodobý koncept fyzioterapie}

Vůbec nejtěžší ve fyzioterapii je ovšem zajištění tzv. dlouhodobého kinezioterapeutického plánu. To znamená naplánování další autoterapie pro klienta po skončení vlastní léčby.

Naplňování dlouhodobého plánu je pochopitelně především $\mathrm{v}$ režii samotného klienta. Pokud nebude sám chtít pokračovat v započaté léčbě, nikdo ho k tomu nemůže nutit. $\mathrm{Na}$ kvalifikovaném fyzioterapeutovi pak tedy leží tíha odpovědnosti za to, jak klientovi nutnost pokra- 
čování fyzioterapie vysvětlí (Lewit, 2003). To je ale bohužel v současné době pověstným kamenem úrazu.

Většina graduovaných fyzioterapeutů se ve své praxi setkává s tradičním modelem fyzioterapie - klient má určité obtíže, navštíví rehabilitačního lékaře, který mu předepíše fyzioterapii. Dle vybavenosti zdravotnického zařizení pak probíhá fyzioterapie ve formě nejrůznějších procedur fyzikální terapie (koupele, elektroléčba, parafín, masáže) včetně individuální fyzioterapie. Zde se terapeut věnuje problematickým místům klienta, aplikuje specifické techniky pro uvolnění svalstva, kloubů apod. a v závěru terapie ho edukuje. Poslední bod je ovšem nejdůležitější ze všeho. Edukace jako taková se většinou dosti zanedbává. Přitom je $z$ hlediska úspěchů terapie, resp. udržení výsledků léčby u klienta rozhodně tou nejvýznamější.

Přesvědčit klienta, že cvičení nebo vůbec nějaký pravidelný pohyb, popř. protahování a různé další doplňkové rekreační sportování je z hlediska efektivity terapie možná důležitější než samotná terapie. Klient nesmí být jen pasivním př́jemcem terapeutické snahy zdravotníka, musí se aktivně podílet na udržení vlastního zdraví.

\section{ZÁVĚR}

V moderní fyzioterapii je třeba klást velký důraz nejen na biologické aspekty terapie, ale i ty psychosociální. Kvalifikovaný fyzioterapeut se musí zajímat o způsoby následné fyzioterapie, kterou provádí sám klient po skončení terapie, at' už ve formě doporučených cvičení nebo rekreačních sportovních aktivit. Edukace klienta je tím nejdůležitějším piliŕrem celé léčby. Zájem o klienta v komplexním pohledu, tedy kromě biologické- ho i v psychosociálním, etickým, spirituálním a dalších, bude do budoucna rozhodující pro dobrý výsledek terapeutického vztahu. Konkurence je díky komerčnímu rozvoji některých metod fyzioterapie obrovská a kvalitní odborník v oboru fyzioterapie by měl svou prací klienta přesvědčit, že mu jde nejen o jeho zdraví, ale především o jeho celou osobnost.

\section{LITERATURA}

DANZER, G.: Psychosomatika. Praha: Portál, 2001. 248 s. DVOŘÁK, R.: Základy kinezioterapie. Olomouc: UP FTK, 2003.

DYLEVSKÝ, I., KUBÁLKOVÁ, L. NAVRÁTIL, L.: Kineziologie, kinezioterapie a fyzioterapie. Praha: Manus, 2001.

GÚTH, A. a kol.: Liečebné metodiky v rehabilitácii pre fyzioterapeutov. 1. vyd. Bratislava: LIEČREH, 2004. s. 470.

HROMÁDKOVÁ, J. a kol.: Fyzioterapie. Jinočany: $\mathrm{H}+\mathrm{H}, 1999$

IŠTOŇOVÁ, M., KOCIOVÁ, K. a kol.: V̌̌eobecná fyzioterapia. 1. vyd. Prešov: Fakulta zdravotníctva Prešovskej univerzity v Prešove. 2008. $180 \mathrm{~s}$

JAVU゚REK, J.: Propedeutika fyzioterapie a rehabilitace. Praha: Karolinum, 1999.

LEWIT, K.: Manipulačni léčba v myoskeletální medicině. Praha: ČLS JEP, 2003.

MIKULÁKOVÁ, W., KOCIOVÁ, K., IŠTOŇOVÁ, M.: Rehabilitačné ošetrovatel'stvo. 1. vyd. Prešov: Fakulta zdravotníctva Prešovskej univerzity v Prešove. 2007. $106 \mathrm{~s}$

RYCHLÍKOVÁ, E.: Funkční poruchy kloubů končetin: diagnostika a léçba. Praha: Grada, 2002.

SAMUELSON, P. A.: Ekonomie. Praha: Svoboda, 1995. $1011 \mathrm{~s}$.

TOMEŠ, I.: Sociální politika. Praha: Socioklub, 2001. $262 \mathrm{~s}$.

ZLÁMAL, J.: Ekonomika zdravotnictví. Brno: Národní centrum ošetřovatelství a nelékařských zdravotnických oborů, 2005. $206 \mathrm{~s}$.

ŽÁK, S.: Religiózní rozměr terapeutického vztahu. In: Kvalita života a zdraví. Praha: Triton, 2005. 629 s.

Marek Zeman marek-zeman@seznam.cz 